\title{
Post Reforms Cropping Dimensions of the Agriculture of the State of Maharashtra in India (1990-91 to 2010-11)
}

\author{
Dnyandev C. Talule \\ Department of Economics, Shivaji University, Kolhapur (MH), India
}

Copyright (C) 2015 Horizon Research Publishing All rights reserved.

\begin{abstract}
Even though the state of Maharashtra has emerged as one of the fastest urbanizing states in the country, the agriculture of the state is not away from making strides. Despite a decline of the share of agriculture in the state GSDP and while on the industrial front the state enjoying quiet a higher position the agriculture sector of the state has been successful in keeping its place intact. Apart from its direct impact on generating incomes and rural employment opportunities its vital secondary linkages with the development of rural nonfarm sectors are more significant. During the period of the economic reforms, the agriculture of the state has undergone a transformation. The sector has made significant strides in its cropping and productivity dimensions. It is with this primary observation the present paper attempts to throw light on the cropping and productivity dimensions of the state agriculture and the determinants of the same. Comparative impacts of the factors determining the crop combination and yield levels are assessed with the help of regression analysis. Paper being depended on secondary sources pulled in for twenty years of period of post reforms of $1990-91$ to $2010-11$ is spread into seven sections with first giving the introduction while the second section provides cropping and yield perspective of the agriculture of Maharashtra. Third section of the paper provides the sources of data and discusses the methodology and tools of analysis and is followed by a brief review of literature on the determinants of crop yield while subsequent two sections of the paper are based on the results and discussions and the test results and the exercise is completed with the concluding remarks in the seventh section whereas; the referential data tables are provided in the annexure for references.
\end{abstract}

Keywords Yield, Productivity, Production, Cultivation, Horticulture, Vegetables, Cash Crops

\section{Introduction}

Maharashtra is one of the fastest urbanizing states in India. More than 46 per cent of the state population resides in urban agglomerations. Rural urban migration rate of the state is highest among all other states in the country. On industrial front also the state enjoys quiet higher ranking in the country. Paradoxically, however, the state also enjoys the dubious distinction of having highest rural-urban disparity in standard of living of its population. Despite having a longest experience of state sponsored employment guarantee programme, in the state the incidence of poverty (31 per cent) is above the national average of 29 per cent.

The share of agriculture in the net state domestic product (GSDP) of the state declined sharply from 36 per cent in 1961-62 to 18.7 per cent in 1992-93 and further to 13 per cent in 2009-10. For the Indian agriculture, the comparable shares were 47 per cent, 27 per cent and 14.5 per cent; still, in terms of the proportion of labour force engaged in agriculture which was 60 per cent in 1991 has marginally declined to 58.5 per cent in 2009-10. This shows that the state's economy continues to be predominantly based on agriculture. Nearly half of the agricultural workers being labourers, in 1991 the share of state's rural labour force employed in agriculture by main workers was as high as 83 per cent. This shows that the crucial dependence of its rural labour force on agriculture is quite evident. This is unlikely to diminish drastically in the near future. In this background the importance of accelerated growth in Maharashtra's agriculture needs to be judged.

Apart from the direct impact of state's agricultural growth on generating incomes and rural employment opportunities its significant secondary linkages with the development of rural non-farm sectors are more significant. Trade in agricultural outputs and inputs and services required by the sector and processing of the products open up additional and more significant avenues for labour absorption. The state being an important producer of processable crops like cotton, sugarcane, oilseeds and quite a few horticultural crops like the grapes such secondary linkages of agriculture have assumed added significance to its rural economy. This 
assumes more significance in the context of liberalized trade regime including farm products. Therefore the careful periodic assessment of the state's agriculture and its performance is necessary for the future prospects of growth. Keeping in view the fact the present study has undertaken this exercise. Mainly the focus is on the decadal comparison from 1960-61 to 1990-91, covering the period of early and the latter phase of the green revolution and from 1990-91 to 2001-02 which marks the comparison between the pre and post economic reforms period

\section{Cropping and Yield Perspective of Maharashtra}

The pattern of crop mix of the state of Maharashtra has a wide perspective ranging from pure rain fed crops like pulses and millets to high value crops which include vegetables and wine grapes orchards as well as export oriented floricultural crops grown under controlled conditions demanding high capital investment in green houses and biotechnology. Agriculturally, the state can be divided in to two separate parts; i.e. the 1) advanced and 2) developing divisions on the basis of the category of crops cultivated. High value crops that are grown in the state are vegetables, onions, wheat, rice, sugarcane, cotton, soya beans, horticultural crops, floriculture, etc. whereas; the low value seasonal crops include food grains and pulses such as the rice, wheat, Jowar, bajra, tur, mung, millets and lentil crops, etc. The agriculture of the state of Maharashtra has experienced a boom in horticultural crops such as the mangos, sapota, guava, grapes, ber, pomegranates and custard apples. It is mainly due to a revolutionary decision of the state government linking employment guarantee scheme to cover the plantation and maintenance cost of private orchids. Basically, the northern and north western Maharashtra consisting of Sholapur, Satara, Sangali, Kolhapur, Pune, Nasik, Ahmednagar, Jalgaon, and Osmanabad districts are traditionally famous for high value crop mix pattern consisting of sugarcane, grapes, vegetables and floriculture. It is mainly due to the availability of the large size multipurpose river valley projects along Koyna, Venna, Krishna, Bhīma, Sina, Godavari, Mula and Pravara rivers whereas; other parts of the state such as the Vidarbha, Konkan and Marathwada have to concentrate on rain fed and relatively low value crops such as the pulses, cotton and food crops like Jowar, Bajra and oilseeds like safflower and soya beans. Recently the farmers of the Western Maharashtra division of the state started growing a different range of varieties of crops like sweet lemon, oranges, ber, pomegranates, etc... This is mainly with the help of their investment in well irrigation supported with pump sets and PVC pipe line network. As a result of the change in attitude of farmers and availability of high yielding verities of the seeds and agricultural service centers at the local village level, the cropping pattern of these parts of the state has also undergone a sea-change. This has happened more prominently during the period of twenty years.

This part of the book consists of an in depth and data based division wise analysis about the periodic crop mix and yield dimensions of the state agriculture sector of Maharashtra. Mainly the period chosen for this analysis is entire reforms period of twenty years of 1990-91 to 2009-10. This makes an interpretation for over a period of twenty years (1991 to2010) that is chosen for the purpose. The data are pulled in from the government records and from other authentic sources such as the EPW research foundation. Data are processed with statistical techniques such as the correlations, averages, trend calculation, growth rates, periodic percentage change and compounded average growth rates. Interpretation is attempted in the context of the practical experience, as well as, past and envisaged agricultural policies of the state and the nation as a whole.

\section{Data and Methodology}

Mainly the argument of the present paper attempts to trace the overall situation of cropping dimensions of the state specific agriculture of the state of Maharashtra, one of the agriculturally progressive states in India. . Mainly the argument concentrates on trends in production and productivity in agriculture with a specific eye on the state of Maharashtra. As the major objective is to concentrate on agricultural production and productivity and cropping pattern of the state agriculture, the data were obtained mainly from the secondary sources i.e. the documents of agricultural departments of the state government of Maharashtra, Agricultural Produce Market Committees (APMCs) and the Statistical Survey of the Ministry of Agriculture, Govt. of India. Other sources such as the CMIE and statistical abstracts of the government were also used for the purpose.

Statistics on the area under major crops, production, productivity, prices, irrigation and trends in rainfall of Maharashtra were obtained from the Economic and Political Weekly research foundation and from the season and crop reports for various years.

Statistical techniques that are used to process the data are as under;

\section{Literature Perspective}

Agricultural yield levels depend on various technical as well as institutional factors. These include infrastructure, markets, stimulative prices, irrigation, etc. (Venkatchalam, 2003). Apart from these technical and other factors the yield levels also depend on the methods of practicing of cultivation and the crop rotations and crop mix practiced by cultivators (N. S. Thakur, 2003). In the agriculture with limited penetration of irrigation the rising yield of rain fed lands has been one of the most difficult challenges of agricultural development in the country (Vaidyanathan, 2006). Looking at the crop mix and the rotation Soya 
bean-Chickpea cropping system was most productive followed by Maize + Soya bean chickpea system (Tomar et. al. 1996, Raskar et. al. 2000). The good potential yield and reasonable market price of a Soya bean and chickpea were major factors responsible for higher production in Andhra Pradesh (Reddy and Reddy 2005) whereas; apart from production and marketing constraints of sunflower cultivation in Andhra Pradesh the rainfall was a serious bottleneck to increase sunflower production (Padmavati (2005). Singh and Rathore (2003) in a study on an influence of phosphorus on yield and economics of green gram found that the grain yield was increased significantly with each successive increase in phosphorous levels up to $50 \mathrm{~kg} \mathrm{P}_{2} \mathrm{O}_{5}$ $\mathrm{ha}^{-1}$ by 23.4 per cent and 7.17 per cent over control and $25 \mathrm{~kg}$ $\mathrm{P}_{2} \mathrm{O}_{5} \mathrm{ha}^{-1}$ respectively. Apart from the yield level and rural transportation nexus observed by Spencer (1994) and IFAD (1995) there have been quiet a sufficient amount of studies stating that better roads are instrumental in reducing the cost of inputs and extension services as well as increase in the scope of profitable trade encouraging farm investment and finally the agricultural production (also see Gregory and Bumb, 2008; Ahmed and Hossain, 1990; Dercon et al. 2009; Van de Walle, 2002; Gollin and Rogersson, 2010; Khandekar, 1989; Singh, 1983; Mazumdar, 2002; Biswanger, et al. ,1993; Khachatryan, et al., 2005). Another set of studies highlighting the irrigation infrastructure and agricultural productivity nexus pointed out that the investment in irrigation both by the public and private farm households results in higher agriculture output (see, AFDB, 2011; Dhawan, 1988; Vaidyanathan, 1999; Thorat and Sirihi, 2001; Manalili and Gonzales, 2009; Fan and Hazell, 1999; Zhang and Fan, 2000; Fan et al., 2000a; 2000B; 2002; Narayanmoorthy and Hanjra, 2006). It is clear from the above cited scholarly attempts establishing a relationship between the technological and institutional factors that the agricultural yield and cropping patterns are the resultant outcome of thoughtful effort at the farm and policy level.

\section{Cropping Dimension in the State of Maharashtra: A Crop Specific Discussion}

Agriculturally, the state of Maharashtra can be divided into two separate parts; one the agriculturally advanced and two; the developing divisions. This can be on the basis of the category of crops cultivated. The high value crops that are grown in the state include vegetables, onions, sugarcane, cotton, horticultural crops and floriculture whereas; the low value seasonal crops include food-grains, lentils and pulses such as the rice, wheat, jowar, bajra, tur, mung, millets, etc.

i. Rice: Pune district in the styate of Maharashtra can be considered as significant in Rice cultivation. Hilly areas of the district with sufficiently good amount of rainfall attract the farmers to cultivate Rice. But recently due to the expansion of the limits of Pune city and thereby the demand for vegetables have been instrumental in shifting farmers from their traditional cultivation of Rice to vegetables. All divisions across the state have shown declining trend in Rice cultivation. Konkan due to its topography and monsoon is mainly suitable for cultivation of Rice which also has shown a shift away from the crop in last twenty years. In the case of Kolhapur, Nagpur and Latur divisions the decline in the area under Rice cultivation has been of the highest order i.e. 94 per cent, 74 per cent and 87 per cent respectively whereas; the division like Aurangabad has remained constant in cultivation of this crop. Overall production of Rice in Maharashtra during the twenty years of the reforms period (1990-91 to 2009-10) has substantially declined. The higher amount of decline is shown by Kolhapur (97 per cent), Latur (94 per cent), Nagpur (94 per cent) and Nasik (51 per cent) divisions respectively. Mainly this decline can be attributed to a decline in the area under Rice. In Amravati and Aurangabad divisions, production of rice did not show any negative trends whereas; in case of Amravati division, a good amount of rainfall and suitable weather conditions help keeping the production of Rice constant and intact. Except Kolhapur and Nagpur, the productivity of Rice across all divisions in the state of Maharashtra mostly has shown a negative trend whereas; the productivity of Rice in Latur, Aurangabad and Konkan division is lower than other divisions. Periodic trends in area, production, productivity and prices of Rice for the entire study period of twenty years show that the area under Rice has slightly declined whereas; the production, productivity and prices have increased.

ii. Jowar: This is a major staple crop of Maharashtra. More than 45 per cent of the total Jowar production of the country is contributed from the state cultivation alone. A secular decline in cultivation of Jowar across all divisions can be attributed to a shift away of farmers from cultivation more in favors of other crops and particularly the cash crops. Nasik division clearly has shown a favor for the cultivation of other seasonal crops such as the maize and vegetable crops whereas; in Nagpur division the crop of Jowar is substituted by Soybeans and Tur. Apart from the specific trends the production of Jowar in all divisions of the state declined and the major amount of decline took place in Nagpur division. In Maharashtra Jowar is one of the traditional staple crops grown both under irrigated and dry land conditions and hence in divisions like Nagpur, the crop of Jowar is cultivated as a sub crop with cotton and tur therefore the per acre 
plant population of the crop remains less than when it is cultivated as the main crop. Hence the productivity of Jowar for Nagpur division remains one of the lowest. It is also observed that in the state the area under Jowar and production has shown a trend of sharp decline whereas; the productivity remained fluctuating.

iii. Wheat: Across all divisions of the state where Wheat is cultivated (except Konkan) the area under cultivation depicted the trend of increase. Secular increase in the area under Wheat across all divisions of the state can be attributed to the factors, such as the significance of the crop in the national consumption basket, availability of national level market for the produce and increasing prices in the recent past. The area under cultivation of Wheat for the entire state showed an increase with exponential proportion but the periodic fluctuations depict a number of ups and downs. Production of Wheat in Maharashtra also has increased substantially with only an exception of Konkan division. There have been some periodic fluctuations in the production of Wheat but overall state production for twenty years has increased quite substantially. Trends in productivity of wheat for almost all divisions showed that it was less than the average of the states like Punjab, Haryana, Rajasthan and western Uttar Pradesh. Konkan being a coastal region of the state therefore in case of Wheat the better performance cannot be expected because the agro climatic conditions of the division are not suitable for the crop. Overall conclusion about the crop emerges that the state farmers need to improve a lot on productivity and their performance in Wheat cultivation. In Maharashtra despite being a large amount of the area under Wheat the total production of the state is less than expected and also the state lags behind the Wheat region states like Punjab, Western UP and Haryana. During the entire study period of 20 years the price of Wheat was shot up by 300 per cent which cannot be linked to the domestic conditions alone. Because the Wheat price is impacted by a number of international factors such as the world production, diversion in the use, subsidy, minimum support price, drought and rainfall etc.

iv. Bajra: This happens to be one of the important staple crops that is cultivated in the state of Maharashtra during the Kharif season. The crop is cultivated both under rain fed and irrigated conditions. It is cultivated by an average category of land holders of the state ( small \& marginal) and those who depend on monsoon for their cultivation practices. Division wise situations of the area under Bajra, showed that it has lost its significance in the state crop mix. As Bajra cannot sustain under the heavy rainfall, so it cannot cultivated in Konkan division whereas; it is cultivated on a very small portion of the land in Nagpur division. Mainly due to the secular decline in the division wise area under Bajra, the total production of the crop in the entire state has declined substantially. Except Nagpur and Kolhapur division, per hectare productivity of Bajra has increased in all other divisions. Overall state situation about the significance of Bajra in the state crop mix, production and productivity showed that both the area under the crop and production have declined by 46 and 24 per cent whereas; the productivity has improved by 41 per cent respectively. Price trends for Bajra also showed a similar picture like that of the other agricultural products which during the period between 1990-91 to 2010-11 has increased by 367 per cent.

v. Maize: Increase in cultivation of Maize across all divisions in the state agriculture of Maharashtra is cutting the space for other crops. When compared the hecterage of the area under Maize between the base year (1990-91) and the last year (2009-10) of the study period it was found that in Pune division the area under this crop has jumped from 33000 ha to 112900 ha. respectively. The output of Maize in Maharashtra has slightly followed by an increase in the area under the crop. Maize being better income fetching due to its better price it emerged that the farmers have successfully tried to enhance production of the same across all divisions of the state of Maharashtra. Productivity of Maize across all divisions of the state showed a somewhat mixed trend. Except one division i.e. Amravati, productivity $(\mathrm{kg} / \mathrm{ha})$ of the crop for all remaining divisions showed a fluctuating trend for the entire study period of twenty years. It was not surprising for Konkan division showing substantial decline as the division is not being agro climatically suitable for Maize cultivation on account its topography and heavy monsoon. Nagpur division where majority of the farmers cultivate cotton (and recently followed by Soybeans) on priority basis and in the same part of the state the rice is preferred over other crops. Looking at the all indicators of the performance of Maize across all divisions of the state, the data show that the overall performance of the crop for the entire study period (i.e. 1990-91 to 2009-10) happened to be exponential. As it is a well-established fact for that the price and farmers' responsiveness to the crop cultivation are always positively associated, it was also found true in the case of Maize as the area, 
productivity and production have shown a substantial increase when the price for it during the study period was increased. Despite a decline in the rainfall and stagnation of the area under irrigation in the entire state the area under the crop, its productivity and its production have increased mainly because of the increase in price.

vi. Cereals: This category of crops mainly includes two categories of food crops. There are core cereals and super cereals. Core cereals include Jowar, Bajra, Ragi, Single and small millets like Nachani and Ragi whereas; the super cereals include main food crops like Rice and Wheat. Maharashtra has emerged as the fastest urbanizing state with more than 46 per cent of its population residing in urbanized agglomerations and industrial estates. Division wise data for the entire state for twenty year period about the area under total cereals show that it has declined across all divisions of the state. The division wise data on production of total cereals show that for the twenty years period the production has increased in most of the divisions (Pune, Nasik, Kolhapur, Aurangabad and Konkan). There are three divisions in the state where the production of cereals has come down. These are Amravati, Latur and Nagpur divisions. As most of the cereals are cultivated under rain fed conditions, cereals productivity for almost all divisions is observed at the lower side. Hence the performance of monsoon becomes a predominant determinant of productivity. Therefore the overall productivity of cereals in Maharashtra for the period of twenty years remained at lower side. Productivity of cereals in Nasik, Amravati, Kolhapur, Nagpur and Konkan division is better than rest of the divisions of Maharashtra. Productivity of cereals in Pune division is one of the lowest in the state. It is mainly because that the farmers of Pune division have more concentration towards cash crops such as the fruits and vegetables. Overall state area under cereals and the production show that there was a sharp decline in last twenty years. But the performance on productivity front has been better.

vii. Gram: In Maharashtra, Gram is cultivated mainly during the Rabbi season. This is a crop cultivated under rain fed, as well as, irrigated conditions. This is one of the major seasonal cash crops cultivated in the state. Except Konkan division in all other divisions, the area under the crop has shown a substantial rise. This is a four month duration crop which can fetch a substantial amount of returns for the cultivators. The data on division wise production of Gram in the state of Maharashtra show an exponential rise.
Except for a short period of 2000-05, in Amravati and Kolhapur and for 1995-2005 in Konkan division the production of Gram across all divisions of the state has increased. Looking at the data and periodic proportion of change during the entire period of 20 years, it shows that the productivity of Gram has increased substantially. New varieties of seeds, better care and on farm management by the farmers have been instrumental in increasing yield level. Overall picture of the cultivation of Gram in the state which emerges from the area under the crop, its production and its price shows that during the period of the economic reforms the crop has emerged as better revenue fetching for the state farmers.

viii. Arhar: Like other cash crops, Tur (Arhar) is also an important multistate crop grown both under the rain fed and irrigated conditions. Dominant states which cultivate Tur are Maharashtra, Andhra Pradesh, Karnataka and Tamil Nadu. This being a lentil crop is used in consumption across all states of the country. Division wise trends of production of Tur shown that except Pune, Nashik and Kolhapur divisions of the state, the production in remaining all divisions of state have shown an exponential increase. Barring only two divisions i.e. Nasik and Kolhapur, the productivity of Tur has shown an exceptional increase. It shows that the farmers must have depended themselves on better quality seeds and integrated pest management. Overall state's area under Tur, total state production and productivity across all divisions of Maharashtra bring out a positive picture.

ix. Urad: Traditionally the Urad is not a preferred variety in all divisions of the state. It is observed that except two divisions of the state (i.e. Pune \& Latur) in all other divisions Urad has lost its significance form the state cropping pattern. Relatively the Nasik, Amravati and Latur divisions are seen ahead in the area under Urad. For the production of Urad, the four divisions viz; Nasik, Amravati, Latur and Aurangabad are ahead but the growth rates for the entire study period are negative. Except one division (i.e. Pune) the productivity of Urad across all divisions in the state has declined sharply. Decline in productivity of Urad can be attributed to the cultivation of the crop under rain fed conditions. All the indicators for all divisions i.e. the area under Urad, its production and productivity have declined with a substantial proportion of 11 per cent, 38 per cent and 30 per cent respectively. As a result of this decline in all these indicators which caused a constraint on supply side has led towards an increase in market 
price of Urad by 425 per cent during the period of twenty years.

$\mathrm{X}$.

Mung: Traditionally the Mung used to be an important lentil crop grown across all divisions of Maharashtra. Mainly the crop is grown under rain fed conditions. But looking at the division wise picture of the land under this crop across all division of the state has shown a sharp declining trend. As already noted in the foregoing analysis that due to the rain fed nature of the crop its production remained low and hence income to the farmers which led them shifting away from cultivation of the crop in all divisions. Looking into the division wise total production of Mung in the state agriculture of Maharashtra, it shows that except a slight increase of 3 per cent in Pune division, the production had almost uniformly declined across all divisions whereas; the productivity of twenty years state has shown somewhat mixed picture for the study period.

It is not the case of the state of Maharashtra alone that the productivity of a lentil / pulses crops has declined but the same can be observed at all India level. The green revolution and other measures of agricultural development remained inadequate for the development of pulses. Interestingly all pulses crops consist of the major part of the food basket of majority of the poor Indians. Decline in rainfall has negatively affected productivity of the crops like Mung. This means that the pure rain fed nature of the crop cannot be profitable for cultivators hence a decline in the area is not unnatural.

xi. Pulses: There is a substantial area under pulses in Maharashtra. But in Nasik, Kolhapur and Aurangabad division the area under pulses had declined during the study period whereas; the same had increased in Amravati, Latur, Nagpur and Konkan divisions. Production of pulses has uniformly increased across all divisions of Maharashtra. The highest amount of production of pulses is realized in Amravati division followed by Nagpur and Nasik division respectively. Increase in productivity of pulses shows that the farmers have started cultivating pulses with better crop care and treatment but it is not sufficient for domestic consumption so that the country needs to import it on large scale from countries such as the Brazil. About state level overall picture, it emerges that barring few intervals the total areas under pulses, production and productivity have increased substantially.

xii. Groundnut: It is a crop cultivated both under the rain fed and irrigated conditions. Crop has its significance in Maharashtra, North Karnataka, Gujarat and Andhra Pradesh. For total production of Groundnut in Maharashtra, Kolhapur division is seen to have been leading. Productivity trends of Groundnut over the years (1990-91 to 2009-10) have remained similar like other cereals and course cereal that are cultivated in the state. Overall state level picture of Maharashtra about the area under Groundnut, its production and its productivity reflects the trend of satisfaction. Mainly the Groundnut price started increasing from the period of 1998-99.

xiii. Soya beans: Increase in the area under cultivation of Soybeans in all the divisions of Maharashtra is relatively a recent Phenomenon. It is clear that soybean has emerged as a dominant crop in Amravati and Nagpur divisions. The division wise productivity trends of soybean showed the trends that the crop production of Amravati, Kolhapur and Nagpur divisions contribute significantly to the state basket. Looking at the productivity $(\mathrm{kg} / \mathrm{ha})$ of Soybeans it was observed that except Kolhapur, Nasik and Aurangabad, all other divisions in the state have shown a negative trend of growth between 1990-91 and 2009-10.

xiv. Sunflower This is another significant oil seed category crop cultivated in all three seasons of Kharif, Rabbi and summer. In some parts of the state, Sunflower is cultivated as an intercrop with Jowar, Gram and Wheat. Division-wise area under sunflower shows that the crop has greater share in the crop mix of Latur, Pune, Aurangabad, and Amravati divisions respectively. In case of production of the Sunflower; Latur, Aurangabad, Pune and Amravati divisions are relatively better over the other divisions. Price for Sunflower in last twenty years has increased by 269 per cent. Overall area under Sunflower in the entire state has declined by 59 per cent whereas; the production by 56 per cent. Sunflower being a significant oil Seed category crop and as the supply of it has declined it led towards an increase in price, as well as, an increase in the price of Sunflower edible oil. This is not cultivated as the principal crop instead cultivated as an inter crop with Jowar, Gram or Wheat during the Rabi season. Mainly four divisions such as the Latur, Amravati, Kolhapur and Aurangabad have emerged as ahead in cultivating safflower. Looking at the overall change in the area under safflower in different divisions of the state it shows that barring few exceptions it has uniformly declined. Mainly the Latur and Aurangabad divisions showed a better traditions of contributing to the state oil seeds basket whereas; the trend is followed by Pune and Amravati divisions. For the entire study period, it shows that excluding some periodic fluctuations the overall productivity of Safflower 
in all divisions (other than Konkan) remained satisfactory. From the area under Safflower, its production, its productivity and its price show that both the area under the crop and production in the state during the twenty year period have declined whereas; productivity has depicted a mixed trend. Looking at the periodic proportion of change in the price of safflower between 1990-91 and 2009-10 it shows that it has increased by 163 per cent. Mainly the price rise can be attributed to a fall in the output and thereby causing stress on supply side. Production of oilseeds during the study period has increased, mainly in divisions where the area under cultivation was increased. These divisions were Amravati, Kolhapur, Latur and Nagpur. Data on productivity of Oilseeds in Maharashtra reveal that the Kolhapur division has the highest per hectare productivity and this was followed by Konkan division. Productivity trends for the entire study period show that except Nagpur and Konkan division it has increased substantially. Overall productivity dimensions and trends show that the state needs to undertake a focused approach towards improvements in productivity of oil seeds. Data about the area under oilseeds, its production and productivity show that the state farmers have substantially concentrated on oilseeds cultivation during the period of the post reforms. Division wise periodic proportion of change in the area under cotton, it shown that except a slight fall in Nagpur followed by Amravati division, in all other divisions it has increased substantially.

xv. Cotton: Divisions like Nasik, Amravati, Latur, Aurangabad and Nagpur have major share in total cotton production of Maharashtra. For productivity of cotton, the picture shows division wise variations. In this respect the divisions like Nasik, Pune and Aurangabad are ahead of other divisions of the state. Productivity of cotton for different divisions in the state shows a satisfactory trend. Some variations are observed in productivity for few years but the same has again improved. But these productivity gaps also depict that the state productivity is less than the international average. Substantial amount of proportion of change (300 per cent) in cotton price in twenty years can be accrued to an upward shift in minimum support price and the farmers' awareness and agitations. Similarly it also needs to be noted that the prevailing market price of cotton is certainly less than the average per quintal cost of cultivation which pushes farmers into a loss making and thereby debt accumulation. This has become a main reason for many farmers to end life through suicide in Vidarbha division of the state.

xvi. Sugarcane: Traditionally Maharashtra is known for its revolution in the field of sugar cooperatives. Mainly the movement was launched around the period of 1950. Before that, private sugar factories in Ahmednagar, Pune and Kolhapur district were in operation. In Kolhapur district, mainly the sugarcane used to be crushed for (Gur) Jaggary making. Still the Kolhapur Jaggary is famous for its test and quality due to its natural iron richness. Decline in the area under sugarcane is observed which can be attributed to the shift in crop mix in favors of short duration cash crops such as the vegetables and also to an increase in the horticultural plantations. Division wise trend in total production of sugarcane also depicts the similar picture like the area under the crop in Maharashtra. It is observed that the productivity of Sugarcane has increased in four divisions whereas; it has declined in other four divisions. Emergence of the overall state picture regarding the area under Sugarcane production, its productivity and the price realized has shown an increase with a substantial proportion. 


\section{Test Results}

Discussion in the foregoing sections shows that the production and productivity of different crops varies from division to division. It was interesting to notice that how each of the division was different in the production and productivity of different crops when compared to the entire state scenario of Maharashtra. So we formulate the following null hypothesis for all the crops in as under;

' $\mathrm{H}_{0}$ ' There is no significant difference between the production and productivity of different crops in a division and the average production and productivity in Maharashtra.

For the Hypothesis we conducted ' $Z$ ' Test and the results are as under:

\section{i.) ' $Z$ ' Test Results}

Table 1. Production and Productivity Dimensions of Different Crops in Maharashtra

\begin{tabular}{|c|c|c|c|c|c|c|c|c|c|}
\hline Crops & Contents & Pune & Nasik & Amravati & Kolhapur & Latur & $\begin{array}{c}\text { Aurang } \\
\text { abad }\end{array}$ & Nagpur & Konkan \\
\hline \multirow{2}{*}{$\begin{array}{c}\text { Total } \\
\text { cereal }\end{array}$} & Production & $-3.17 *$ & $-2.74 *$ & $2.1 *$ & 1.75 & -1.17 & 0.25 & $2.26^{*}$ & $3.6^{*}$ \\
\hline & Productivity & $8.7^{*}$ & -1.96 & $-5.79 *$ & $-3.45^{*}$ & 1.04 & 1.9 & -1.04 & $-16.24 *$ \\
\hline \multirow{2}{*}{$\begin{array}{c}\text { Total } \\
\text { pulses }\end{array}$} & Production & $6.46^{*}$ & -0.79 & $-9.24 *$ & $10.39 *$ & $-4.48^{*}$ & $3.44 *$ & $2.44^{*}$ & $16.98^{*}$ \\
\hline & Productivity & 1.79 & -1.21 & $-2.19^{*}$ & -1.59 & 1.78 & 1.9 & -0.45 & 0.44 \\
\hline \multirow{2}{*}{$\begin{array}{c}\text { Total } \\
\text { oilseeds }\end{array}$} & Production & $3.99 *$ & $4.85^{*}$ & $-2.69^{*}$ & $-4.42 *$ & -1.89 & $6.59^{*}$ & $-3.36^{*}$ & $12.17 *$ \\
\hline & Productivity & 1.61 & 1.47 & -0.56 & $-8.99 *$ & $4.2 *$ & $5.96^{*}$ & -0.95 & -1.54 \\
\hline \multirow{2}{*}{ Cotton } & Production & $8.46^{*}$ & $-2.6^{*}$ & $-7.02 *$ & $9.25^{*}$ & -1.57 & -1.23 & $2.6^{*}$ & 0 \\
\hline & Productivity & $-4.23 *$ & -1.99 & 0.51 & $-3.27 *$ & 0.98 & -0.07 & 0.76 & 0 \\
\hline \multirow{2}{*}{$\begin{array}{l}\text { Sugar } \\
\text { Cane }\end{array}$} & Production & $-5.59^{*}$ & $2.55^{*}$ & $11.05^{*}$ & $-10.63^{*}$ & 0.28 & $2.12^{*}$ & $12.37 *$ & $13.1^{*}$ \\
\hline & Productivity & -0.87 & 0.66 & $2.46^{*}$ & $-3.45^{*}$ & $3.62 *$ & 1.94 & $4.05^{*}$ & $5.92 *$ \\
\hline
\end{tabular}

*indicate significance of the computed test statistics)

Results of ' $z$ ' test are presented in the above table. Values obtained from total serials show that in Pune and Nasik division the production of cereals is significantly lower than the average production in Maharashtra. For Pune division the sugarcane production is also significantly lower than the average of the entire state. In Aurangabad division the production of pulses, oilseeds and sugarcane is higher than the average of the state. In Konkan division the production of pulses and oilseeds is significantly higher where in Nagpur division the production of pulses and sugarcane when compared to the state is very high. In case of the production of most of the crops, Latur division is significantly lower than that of the state average.

When the ' $Z$ ' values for productivity are considered, it is observed that for almost all divisions the productivity of crops is close to the average productivity at the state level. It therefore can be concluded that there is a significant difference between the production of different crops and the average production for the entire state while productivity of the crops in the divisions does significantly differ from the state average.

\section{ii.) Regression Analysis: Results}

a) Dependent Variable: Production

Table 2. Determinants of Production of Different Crops in the State of Maharashtra

\begin{tabular}{|c|c|c|c|c|c|c|c|c|}
\hline Crop & Const & Prod & P & $\mathrm{F}$ & $\mathrm{R}$ & $\mathrm{I}$ & $\mathrm{A}$ & $\mathrm{R}^{2}$ \\
\hline \multirow{2}{*}{ Cotton } & $\begin{array}{c}-27138.38 \\
(-11.88)\end{array}$ & $\begin{array}{c}183.79^{*} \\
(67.01)\end{array}$ & $\begin{array}{c}-1.499 \\
(-2.18)\end{array}$ & $\begin{array}{c}0.002^{*} \\
(3.28)\end{array}$ & $\begin{array}{c}-2.93 \\
(-2.27)\end{array}$ & $\begin{array}{c}-1.88 \\
(-1.26)\end{array}$ & $\begin{array}{c}1.127^{*} \\
(10.51)\end{array}$ & 0.99 \\
\hline \multirow{2}{*}{ Cereals } & $\begin{array}{c}-98428.22 \\
(-18.01)\end{array}$ & $\begin{array}{c}98.04^{*} \\
(65.80)\end{array}$ & - & $\begin{array}{c}-0.002 \\
(-3.04)\end{array}$ & $\begin{array}{c}0.98 \\
(0.74)\end{array}$ & $\begin{array}{c}0.85 \\
(0.76)\end{array}$ & $\begin{array}{c}0.99^{*} \\
(25.11)\end{array}$ & 0.99 \\
\hline \multirow{2}{*}{ Sugar cane } & $\begin{array}{c}-397843.68 \\
(-12.20)\end{array}$ & $\begin{array}{c}5.98^{*} \\
(13.5)\end{array}$ & $\begin{array}{c}59.37^{*} \\
(2.4)\end{array}$ & $\begin{array}{c}-0.018 \\
(-1.48)\end{array}$ & $\begin{array}{c}-31.80 \\
(-1.91)\end{array}$ & $\begin{array}{c}25.11 \\
(1.56)\end{array}$ & $\begin{array}{c}78.06^{*} \\
(98.96)\end{array}$ & 0.99 \\
\hline \multirow{2}{*}{ Oilseed } & -18004.36 & $\begin{array}{c}32.26^{*} \\
(-3.27)\end{array}$ & - & $\begin{array}{c}0.001 \\
(0.77)\end{array}$ & $\begin{array}{c}-3.76 \\
(-1.58)\end{array}$ & $\begin{array}{c}2.24 \\
(0.84)\end{array}$ & $\begin{array}{c}0.75^{*} \\
(5.53)\end{array}$ & 0.98 \\
\hline \multirow{2}{*}{ Pulses } & $\begin{array}{c}-19289.47 \\
(-13.32)\end{array}$ & $\begin{array}{c}33.95 \\
(32.8)\end{array}$ & - & $\begin{array}{c}0 \\
(1.086)\end{array}$ & $\begin{array}{c}-0.73 \\
(-1.33)\end{array}$ & $\begin{array}{c}0.102 \\
(0.16)\end{array}$ & $\begin{array}{c}0.61 \\
12.18\end{array}$ & 0.99 \\
\hline
\end{tabular}

(* Indicates the significance of the variable)

Notes:Prod=Production, $\mathrm{P}=$ Productivity, $\mathrm{F}=$ Fertilizer Consumption, $\mathrm{R}=$ =Average Rainfall, $\mathrm{I}=$ Irrigated Area of Maharashtra, $\mathrm{A}=$ Area under the crop 
a) Objective of the entire exercise being to understand the production and productivity trends for different crops. Total output of a crop is dependent on a number of variables such as the area under the crops, productivity, use of fertilizer, rainfall and the price of the concerned crop. In order to bring out the most significant variables among these we used the tool of regression analysis. Here we consider production as dependent variable and the remaining as independent variables. Results obtained for sugarcane are presented in the immediate above table.

From the results we observe that among all the variables considered for the study, the productivity, price and area have come out as the most significant variables. The reasons of these coefficients are not only positive but also highly significant. Fertilizers and rainfall do not appear to be significantly influencing the sugarcane production. The value of $\mathrm{R}^{2}$ is also high indicating that the estimated regression model explains most of the variations in the dependant variable.

In case of cotton the total output is observed to have increased mainly due to the increase in area under the crop, improvement in the productivity and use of fertilizers. Values of coefficient of these variables are not only positive but highly significant as shown by the ' $t$ ' values. Price and rainfall have not shown any positive influence on the cotton crop.

b) For studying the relationship between production of cereals and the variables that influenced it, we considered area, rainfall, irrigation, fertilizer use and productivity per hector. Price data for other cereals was not available so it is not included in the regression model. The results obtained for the regression equation with cereals as the results obtained the dependent variable is presented in the above table.

The obtained coefficient and corresponding ' $t$ ' values in the parentheses help to explain the impact of individual variable. From the result it is observed that among all the variables the coefficient of the variable area and productivity are not only positive but also significant as shown by significant ' $t$ ' values. The variables rainfall and irrigation though are of the correct sign; they are not significant as shown by the low ' $t$ ' values. Results indicate that for cereals the total production is influenced by the area under the crop and the productivity per hectare.

We now estimate the regression equation for oilseeds by considering the same independent variable. In this regression model too price data separately for other oilseeds was not available and so it is not included in the model. The results in the table show that, as in the case of cereals, the variables i.e. area under oilseeds crops and productivity per hectare emerged as significant variables. The variables Irrigation and fertilizers used are positive but not significant. The value of $\mathrm{R}^{2}$ is also very high indicating that the overall explanatory power of the model is very good. In other word more than $98 \%$ of the variation in the oilseeds production is explained by the estimated regression equation.

From the regression equation estimated for pulses it is observed that again the variables i.e. area under the crop and productivity are significant as shown by the high ' $t$ ' values. Variables fertilizers and irrigation are not significant. The rainfall is having a negative sign but is found to be insignificant.

\section{b) Dependent Variable: Productivity}

In order to analyze the productivity of various crops, we now consider productivity as dependent variable. Since productivity of crop can be influenced by variables such as the fertilizers use, irrigation, rainfall, area and price. These are considered as the independent variables. Results of regression with productivity as the dependent variable of different crops are presented in the above table (Table 3).

The regression results of the sugarcane crop show that among the entire variables sugarcane price, rainfall and fertilizer emerged as significant variables. Signs of the coefficient are positive and the corresponding ' $t$ ' values are also significant. Area and production variable are showing negative sign and are also significant as shown by the high ' $t$ ' values. The result shows that as the cultivator attempts to bring more area under the said crop and thereby increase the production, the productivity of sugarcane decreases. In other words more the area under sugarcane less is the productivity.

Table 3. Determinants of Productivity of Different Crops in the State of Maharashtra

\begin{tabular}{|c|c|c|c|c|c|c|c|c|}
\hline Crop & Const & Prod. & $\mathrm{F}$ & I & $\mathrm{R}$ & A & $\mathrm{P}$ & $\mathrm{R}^{2}$ \\
\hline Sugarcane & $\begin{array}{c}61341.9 \\
(8.17) \\
\end{array}$ & $\begin{array}{c}-10.7 \\
(-2.96)\end{array}$ & $\begin{array}{l}0.004 * \\
(2.008)\end{array}$ & $\begin{array}{c}-3.02 \\
(-1.12)\end{array}$ & $\begin{array}{l}6.34^{*} \\
(2.56)\end{array}$ & $\begin{array}{l}-12.25^{*} \\
(-13.98)\end{array}$ & $\begin{array}{c}0.15^{*} \\
(13.56)\end{array}$ & 0.98 \\
\hline Cotton & $\begin{array}{l}147.42 \\
(11.8)\end{array}$ & $\begin{array}{c}0.005^{*} \\
67.01\end{array}$ & $\begin{array}{l}-1.26 \\
(-3.18)\end{array}$ & $\begin{array}{c}0.01 \\
(1.24)\end{array}$ & $\begin{array}{l}0.016^{*} \\
(2.32)\end{array}$ & $\begin{array}{l}-0.006^{*} \\
(-10.35)\end{array}$ & $\begin{array}{l}0.008^{*} \\
(2.23)\end{array}$ & 0.99 \\
\hline Cereals & $\begin{array}{c}1000.48 \\
(17.27) \\
\end{array}$ & $\begin{array}{c}0.01^{*} \\
(65.80) \\
\end{array}$ & $\begin{array}{l}2.09^{*} \\
(3.17)\end{array}$ & $\begin{array}{l}-0.008 \\
(-0.74) \\
\end{array}$ & $\begin{array}{c}-0.01 \\
(-0.73) \\
\end{array}$ & $\begin{array}{c}-0.01 * \\
(-21.89) \\
\end{array}$ & - & 0.98 \\
\hline Oilseeds & $\begin{array}{l}455.27 \\
(2.51)\end{array}$ & $\begin{array}{l}0.02 * \\
13.42 \\
\end{array}$ & $\begin{array}{c}-6.42 \\
(-1.16)\end{array}$ & $\begin{array}{c}-0.04 \\
(-0.55)\end{array}$ & $\begin{array}{l}0.14^{*} \\
(2.15)\end{array}$ & $\begin{array}{l}-0.02 * \\
(-4.31) \\
\end{array}$ & - & 0.96 \\
\hline Pulses & $\begin{array}{l}556.51 \\
(11.27) \\
\end{array}$ & $\begin{array}{l}0.02 * \\
32.89 \\
\end{array}$ & $\begin{array}{c}-6.86 \\
(-0.93) \\
\end{array}$ & $\begin{array}{c}-0.02 \\
(-0.11)\end{array}$ & $\begin{array}{c}0.02 \\
(1.32)\end{array}$ & $\begin{array}{l}-0.018^{*} \\
(-10.01) \\
\end{array}$ & - & 0.99 \\
\hline
\end{tabular}

(* Indicates the significance of the variables)

Notes: Prod=Production, $\mathrm{P}=$ Productivity, $\mathrm{F}=$ Fertilizer Consumption, $\mathrm{R}=$ Average Rainfall, $\mathrm{I}=$ =rrigated Area of Maharashtra, $\mathrm{A}=$ Area under the crop 
The results for the cotton crop show that except area and fertilizer use all other variables included in the model are of positive sign and significant. For this crop too the cotton price and the rainfall appear to be the significant variables influencing crop productivity. In other words productivity of cotton is positively influenced by economic and natural variables such as the price and rainfall.

Regression equation for cereals productivity shows that the variables total production, area under the crop and fertilizer use significant. Coefficient of these variables is significant and positive. While irrigation and rainfall variables are obtained as insignificant. Results indicate that for cereals the productivity is mainly influenced by area under the crop, fertilizer use and the total production. It shows that an increase in the area under crop leads to a negative impact on productivity.

In case of the oilseeds equation too we obtain production rainfall and area as significant variables. As in the earlier equation the coefficient of area is observed to be negative, while production and rainfall are having positive coefficient. ' $\mathrm{R}^{2}$ ' value is also high at 0.96 . In other words the productivity of oilseeds is positively influenced by rainfall and negatively by bringing more area under the crop.

The equation for pulses also shows a similar result. In the regression equation only the variables; area and production are significant. All other variables are insignificant and not of the appropriate sign. Explanatory power of the model is also high as the value of ' $\mathrm{R}^{2}$ ' is more than 0.90 .

When we consider all the results together it is clear that the productivity of all the crops is mainly being negatively influenced by the area under the crop. The price variable included in the equation for sugarcane and cotton is significant. Productivity for all crops is not majorly influenced by irrigation facilities and by fertilizers use in case of few crops.

\section{Concluding Remarks}

For the purpose of assessing changes in crop wise production and yield dimensions for the post reforms period a total of sixteen crops from four main categories of serials, pulses, oil seeds and the cash crops like the cotton and sugar cane were chosen. After an elaborate exercise, there is no doubt about the vast changes which have taken place in the production and productivity of all crops under observation. It is clear that the agriculture of the state has undergone two important shifts in its production and productivity related aspects. The first shift has taken place during the late 1970s with the rural electrification as a result of the planned launch of the green revolution and second during the period of the economic reforms of the 1990s.

Mainly the entire analysis of the data showed that the production and productivity of different crops varied from division to division. It was interesting to see as to how the divisions differed in production and productivity of different crops when compared to a state level scenario. Values obtained through ' $Z$ ' test for total serials showed that in Pune and Nasik division the production of cereals was significantly lower than the average production of the state. For Pune division the sugarcane production was also significantly lower than the average of the state. In Aurangabad division the production of pulses, oilseeds and sugarcane was higher than the average of the state. In Konkan division pulses, oilseeds and sugarcane it was significantly higher where in Nagpur division the production of pulses and sugarcane was very high but for most of the crops in Latur division it was significantly lower than that of the state average.

When ' $Z$ ' values for productivity were considered, it was observed that for almost all the division the productivity of the crops in the divisions was close to the average productivity at the state level. So it can therefore be concluded that there was a significant difference between the production of different crops and the average production of those crops for the entire state while productivity of the crops in the division do significantly differ from average of Maharashtra.

Crop output was found to be dependent on a number of variables such as the area under the crop, productivity, use of fertilizer, rainfall and the price. In order to bring out the most significant variables among these, regression analysis considering production as the dependent and the remaining as the independent variables it was observed that among all variables; productivity, price and area have emerged as the most significant variables. From the regression results for serials it was observed that among all variables that coefficient of the variable area and productivity were not only positive but also significant as were shown by ' $t$ ' values whereas; the variables rainfall and irrigation were the correct sign but were not the significant by the low ' $t$ ' values. While analyzing the productivity of various crops by considering it as dependent variable as it can be influenced by variables such as the fertilizer, irrigation, rainfall, area and price the results of the regression for different crops were as; for sugarcane it showed that among all the variables price, rainfall and fertilizers use were the significant variables whereas; for cotton it emerged except area and fertilizer use all other variables included in the model were significant also the price and rainfall appeared to be significant variables influencing productivity. For serials, productivity depended on the area under the crop and fertilizer use. For oilseeds $\left(\mathrm{R}^{2}\right)$ value was high at 0.96 means productivity of oilseeds is positively influenced by rainfall and negatively by bringing more area under the crop cultivation. In case of pulses it showed similar result. In the regression equation only the variables like area and production were significant. This means that the agriculture production in the state is a function of various controllable and uncontrollable variables that have the control over crop productivity and thereby the area under particular crop for the period.

As a result of a continuous increase in prices of the crops like bajra, wheat, gram, tur and pulses during the 1990s, farmers in Maharashtra have shifted their cropping patter in 
favor of these crops and thereby the total production of crops shot up during the entire study period of twenty years. It means that the upward shift in agricultural prices was a pushing factor for the farming community of the state. As a result of increase in price and productivity of cotton during the reforms period, farmers in the state have started growing the crop more than earlier. Similar changes for horticulture, floriculture, medicinal crops/ plants and vegetable are observed. Increase in productivity of most of the crops depicted the commercialization of agriculture in the state at the private farm level. But the potential productivity still remains unachieved as a result of inadequate penetration of irrigation, rural electrification and the limitation of the irritability of groundwater on account of availability of water and uninterrupted supply of electricity accruing to the frequent power cuts termed as load-shading.

Excess use of water and fertilizers in irrigated western Maharashtra has resulted in productivity stagnation of cash crops like sugarcane which invites stringency in water use mechanism which can increase the potential utilization of irrigation projects and also the sustenance of productivity could be possible otherwise the commercial farmers in future might get trapped into the situation of suiciding farmers of Vidarbha region.

Due to the availability of local marketing facilities and increase in prices, the production and area under soya beans have increased sharply but the productivity stagnation demands special efforts. As a result of the vivid decline in productivity of pulses and cereals the area under these crops has decelerated and the place is occupied by increasing area under soybeans, onions, cotton, gram, tur, floriculture, horticulture and vegetables. As a result of the linkage of employment guarantee scheme to horticulture programme the area under these crops in the entire state has gone up but not the productivity. This aspect demands investment boost in processing at local level and betterment of marketing conditions, logistics, transportation and warehousing to en-cash price fluctuations. Broadly, in respect of production, productivity and the shift in area under various crops the agriculture of Maharashtra is at crossroads. Also there is a shift from the traditional livelihood agriculture towards commercial agriculture which is proved from the intercrop substitution. Area under traditional livelihood crops such as the pulses, cereals and oilseeds has gone down and occupied by high value cash crops like sugarcane, soybeans, onions, floriculture, gram, tur, maize, horticulture and cotton. All these crops are irrigation and fertilizer demanding crops also demand better role of the government in education on water and fertilizer use efficiency otherwise the excess use of the same could deplete availability of quality and quantity of water thereby challenging yield levels will make sustainability of the local agriculture difficult in future as has happened in many of the agriculturally progressive states like Punjab and Haryana and has made agriculture a field of distress for cultivation.

\section{Annexure}

Table 4. Copping Intensity of Maharashtra

\begin{tabular}{|c|c|c|c|c|c|c|c|c|c|c|}
\hline 1 & 2 & 3 & 4 & 5 & 6 & 7 & 8 & 9 & 10 & 11 \\
\hline & & \multirow{2}{*}{$1960-61$} & \multirow{2}{*}{$1970-71$} & Change & \multirow{2}{*}{$1980-81$} & Change & \multirow{2}{*}{$1990-91$} & Change & \multirow{2}{*}{$1997-98$} & Change \\
\hline \multicolumn{2}{|c|}{ Districts and Division } & & & $(3-4)$ & & $(4-6)$ & & $(6-8)$ & & $(8-10)$ \\
\hline 1 & Ahmednagar & 105.2 & 105.95 & 0.7 & 108.34 & 2.3 & 117.73 & 8.7 & 119.63 & 1.6 \\
\hline 2 & Kolhapur & 102.69 & 101.12 & -1.5 & 104.75 & 3.6 & 108.55 & 3.6 & 125.26 & 15.4 \\
\hline 3 & Nasik & 107.03 & 104.12 & -2.7 & 110.35 & 6 & 112.64 & 2.1 & 111.01 & -1.4 \\
\hline 4 & Pune & 110.91 & 112.97 & 1.9 & 110.15 & -2.5 & 128.54 & 16.7 & 122.26 & -4.9 \\
\hline 5 & Sangali & 104.04 & 102.05 & -1.9 & 106.89 & 4.7 & 110.06 & 3 & 123.85 & 12.5 \\
\hline 6 & Satara & 111.27 & 110.83 & -0.4 & 113.76 & 2.6 & 120.98 & 6.3 & 126.11 & 4.2 \\
\hline 7 & Sholapur & 103.06 & 103.93 & 0.8 & 109.96 & 5.8 & 105.45 & -4.1 & 107.17 & 1.6 \\
\hline \multicolumn{2}{|c|}{ Western Maharashtra } & 106.31 & 105.85 & -0.44 & 109.17 & 3.21 & 114.85 & 5.18 & 119.32 & 4.14 \\
\hline 8 & Akola & 100.4 & 101.97 & 1.6 & 105.32 & 3.3 & 117.8 & 11.8 & 126.52 & 7.4 \\
\hline 9 & Amravati & 100.66 & 100.8 & 0.1 & 103.64 & 2.8 & 120.37 & 16.1 & 120.36 & 0 \\
\hline 10 & Bhandara & 135.36 & 130.46 & -3.6 & 121.53 & -6.8 & 132.12 & 8.7 & 157.65 & 19.3 \\
\hline 11 & Buldhana & 102.57 & 104.96 & 2.3 & 112.62 & 7.3 & 120.83 & 7.3 & 125.39 & 3.8 \\
\hline 12 & Chandrapur & 107.76 & 108.58 & 0.8 & 106.36 & -2 & 116.05 & 9.1 & 124.18 & 7 \\
\hline 13 & Nagpur & 101.43 & 102.54 & 1.1 & 111.09 & 8.3 & 113.96 & 2.6 & 132.07 & 15.9 \\
\hline
\end{tabular}




\begin{tabular}{|c|c|c|c|c|c|c|c|c|c|c|}
\hline 14 & Wardha & 100.83 & 101.89 & 1.1 & 105.14 & 3.2 & 105.69 & 0.5 & 112.95 & 6.9 \\
\hline 15 & Yavatmal & 100.73 & 101.3 & 0.6 & 101.9 & 0.6 & 108.7 & 6.7 & 117.97 & 8.5 \\
\hline \multicolumn{2}{|c|}{ Vidarbha } & 106.21 & 106.56 & 0.5 & 108.45 & 2.08 & 116.94 & 7.85 & 127.13 & 8.6 \\
\hline 16 & Aurangabad & 104.13 & 106.86 & 2.6 & 110.77 & 3.7 & 126.7 & 14.4 & 119.64 & -5.6 \\
\hline 17 & Beed & 105.71 & 107.11 & 1.3 & 106.17 & -0.9 & 118.64 & 11.7 & 120.34 & 1.4 \\
\hline 18 & Nanded & 102.25 & 103.6 & 1.3 & 105.78 & 2.1 & 123.69 & 16.9 & 113.52 & -8.2 \\
\hline 19 & Osmanabad & 103.29 & 104.9 & 1.6 & 110 & 4.9 & 125.58 & 14.2 & 128.2 & 2.1 \\
\hline 20 & Parbhani & 104.22 & 109.41 & 5 & 113.31 & 3.6 & 139.55 & 23.2 & 134.92 & -3.3 \\
\hline \multicolumn{2}{|c|}{ Marathwada } & 103.92 & 106.376 & 2.36 & 109.206 & 2.68 & 126.832 & 16.08 & 123.324 & -2.72 \\
\hline 21 & Raigad & 105.4 & 126.41 & 19.9 & 117.49 & -7.1 & 107.75 & -8.3 & 112.11 & 4 \\
\hline 22 & Ratnagiri & 103.02 & 103.07 & 0 & 106.38 & 3.2 & 103.95 & -2.3 & 113.04 & 8.7 \\
\hline 23 & Thane & 103.43 & 101.75 & -1.6 & 109.57 & 7.7 & 102.69 & -6.3 & 107.93 & 5.1 \\
\hline \multicolumn{2}{|c|}{ Konkan } & 103.95 & 110.41 & 6.1 & 111.14 & 1.26 & 104.79 & -5.63 & 111.02 & 5.93 \\
\hline 24 & Dhule & 112.77 & 109.01 & -3.3 & 110.85 & 1.7 & 112.11 & 1.1 & 107.65 & -4 \\
\hline 25 & Jalgaon & 106.85 & 108 & 1.1 & 110.74 & 2.5 & 124.94 & 12.8 & 113.83 & -8.9 \\
\hline \multicolumn{2}{|c|}{ North Maharashtra } & 109.81 & 108.5 & -1.1 & 110.79 & 2.1 & 118.52 & 6.95 & 110.74 & -6.45 \\
\hline \multicolumn{2}{|c|}{ Maharashtra } & 105.28 & 106.05 & 0.7 & 109.08 & 2.9 & 117.75 & 7.9 & 120.67 & 2.5 \\
\hline
\end{tabular}

Table 5. Area under Cereals as Proportion of Total Cropped Area of Maharashtra (\%)

\begin{tabular}{|c|c|c|c|c|c|c|c|c|c|c|}
\hline 1 & 2 & 3 & 4 & 5 & 6 & 7 & 8 & 9 & 10 & 11 \\
\hline \multirow{2}{*}{ Sr. No. } & \multirow{2}{*}{ Region } & \multirow{2}{*}{$1960-61$} & \multirow{2}{*}{ 1970-71 } & Change & \multirow{2}{*}{ 1980-81 } & Change & \multirow{2}{*}{ 1990-91 } & Change & \multirow{2}{*}{ 2001-02 } & Change \\
\hline & & & & $(3-4)$ & & $(4-6)$ & & $(6-8)$ & & $(8-10)$ \\
\hline 1 & Western Maharashtra & 64.66 & 64.49 & 0.05 & 63.32 & -1.65 & 63.33 & -0.15 & 58.15 & -9.47 \\
\hline 2 & Vidarbha & 49.7 & 47.34 & -5.96 & 48.14 & 2.17 & 40.04 & -19.5 & 28.76 & -32.02 \\
\hline 3 & Marathwada & 52.42 & 51.87 & -1.28 & 53.49 & 3.52 & 47.62 & -10.96 & 47.98 & 0.2 \\
\hline 4 & Konkan & 65.99 & 71.27 & 7.633 & 68.02 & -3.93 & 65.18 & -5.26 & 46.8 & -28.26 \\
\hline 5 & North Maharashtra & 45.16 & 44.32 & -1.5 & 50.265 & 14.4 & 47.37 & -5.2 & 40.55 & -16.4 \\
\hline 6 & Maharashtra & 56.34 & 55.08 & -2.2 & 55.88 & 1.5 & 50.94 & -8.8 & 44.8 & -12.1 \\
\hline
\end{tabular}

Table 6. Area under Pulses as Proportion of Total Cropped Area in Maharashtra (\%)

\begin{tabular}{|c|c|c|c|c|c|c|c|c|c|c|}
\hline 1 & 2 & 3 & 4 & 5 & 6 & 7 & 8 & 9 & 10 & 11 \\
\hline \multirow{2}{*}{ Sr. No. } & \multirow{2}{*}{ Region } & \multirow{2}{*}{$1960-61$} & \multirow{2}{*}{ 1970-71 } & Change & \multirow{2}{*}{$1980-81$} & Change & \multirow{2}{*}{ 1990-91 } & Change & \multirow{2}{*}{ 2001-02 } & Change \\
\hline & & & & $(3-4)$ & & $(4-6)$ & & $(6-8)$ & & $(8-10)$ \\
\hline 1 & Western Maharashtra & 8.33 & 8.71 & 4.18 & 9.81 & 19.92 & 8.8 & -8.17 & 9.2 & 6.9 \\
\hline 2 & Vidarbha & 13.25 & 13.36 & 1.28 & 13.17 & -0.66 & 18.61 & 48.55 & 20.51 & 8.91 \\
\hline 3 & Marathwada & 16.13 & 18.72 & 18.8 & 12.55 & -36.3 & 16.85 & -43.52 & 18.96 & 14.26 \\
\hline 4 & Konkan & 4.54 & 3.53 & -22.2 & 3.21 & -5.73 & 4.31 & 28.06 & 4.96 & 22.63 \\
\hline 5 & North Maharashtra & 18.68 & 19.86 & 9.85 & 17.86 & -9.05 & 18.65 & 4.8 & 15.9 & -14.75 \\
\hline 6 & Maharashtra & 12.49 & 1.7 & -86.4 & 13.82 & 712.9 & 14.9 & 7.8 & 16.8 & 12.8 \\
\hline
\end{tabular}


Table 7. Area under Food grains as Proportion of the total Cropped Area in Maharashtra (\%)

\begin{tabular}{|c|c|c|c|c|c|c|c|c|c|c|}
\hline 1 & 2 & 3 & 4 & 5 & 6 & 7 & 8 & 9 & 10 & 11 \\
\hline \multirow{2}{*}{ Sr. No. } & \multirow{2}{*}{ Region } & \multirow{2}{*}{$1960-61$} & \multirow{2}{*}{ 1970-71 } & Change & \multirow{2}{*}{$1980-81$} & Change & \multirow{2}{*}{ 1990-91 } & Change & \multirow{2}{*}{ 2001-02 } & Change \\
\hline & & & & $(3-4)$ & & $(4-6)$ & & $(6-8)$ & & $(8-10)$ \\
\hline 1 & Western Maharashtra & 73 & 73.21 & 0.2 & 73.59 & 0.84 & 72.13 & -2.08 & 67.37 & -7.77 \\
\hline 2 & Vidarbha & 62.95 & 60.71 & -4.33 & 61.31 & 1.95 & 58.66 & -4.06 & 49.83 & -15.9 \\
\hline 3 & Marathwada & 68.55 & 70.6 & 2.76 & 72.19 & 2.38 & 64.48 & -10.74 & 66.94 & 4.02 \\
\hline 4 & Konkan & 70.53 & 74.81 & 5.73 & 71.23 & -4.16 & 69.5 & -3.63 & 51.63 & -25.83 \\
\hline 5 & North Maharashtra & 63.83 & 64.18 & 0.35 & 68.12 & 6.05 & 66.02 & -2.95 & 56.45 & -15.3 \\
\hline 6 & Maharashtra & 68.83 & 68.77 & -0.1 & 69.7 & 1.4 & 65.84 & -5.5 & 61.6 & -6.5 \\
\hline
\end{tabular}

Table 8. Area under Cotton as Proportion of total Cropped Area in Maharashtra (\%)

\begin{tabular}{|c|c|c|c|c|c|c|c|c|c|c|}
\hline 1 & 2 & 3 & 4 & 5 & 6 & 7 & 8 & 9 & 10 & 11 \\
\hline \multirow{2}{*}{ Sr. No. } & \multirow{2}{*}{ Region } & \multirow{2}{*}{$1960-61$} & \multirow{2}{*}{$1970-71$} & Change & \multirow{2}{*}{$1980-81$} & Change & \multirow{2}{*}{ 1990-91 } & Change & \multirow{2}{*}{ 2001-02 } & Change \\
\hline & & & & $(3-4)$ & & $(4-6)$ & & $(6-8)$ & & $(8-10)$ \\
\hline 1 & Western Maharashtra & 0.94 & 1.14 & 44.75 & 0.71 & -35.82 & 0.13 & -76.88 & 0.44 & 197.35 \\
\hline 2 & Vidarbha & 27.3 & 29.67 & 14.71 & 26.04 & -11.1 & 26.33 & 5.8 & 26.71 & 6.83 \\
\hline 3 & Marathwada & 15.54 & 14.942 & -10.96 & 12.88 & -20.66 & 12.22 & -18.88 & 16.88 & 103.9 \\
\hline 4 & Konkan & 0 & 0 & 0 & 0 & 0 & 0 & 0 & 0 & 0 \\
\hline 5 & North Maharashtra & 16.4 & 18.43 & 7.75 & 13.95 & -20.35 & 12.99 & -2.6 & 28.95 & 114.3 \\
\hline 6 & Maharashtra & 13.28 & 14.68 & 10.5 & 12.58 & -14.3 & 12.45 & -1 & 14.8 & 18.8 \\
\hline
\end{tabular}

Table 9. Area under Sugarcane as Proportion of Total Cropped Area in Maharashtra (\%)

\begin{tabular}{|c|c|c|c|c|c|c|c|c|c|c|}
\hline 1 & 2 & 3 & 4 & 5 & 6 & 7 & 8 & 9 & 10 & 11 \\
\hline \multirow{2}{*}{ Sr. No. } & \multirow{2}{*}{ Region } & \multirow{2}{*}{$1960-61$} & \multirow{2}{*}{ 1970-71 } & Change & \multirow{2}{*}{$1980-81$} & Change & \multirow{2}{*}{$1990-91$} & Change & \multirow{2}{*}{ 2001-02 } & Change \\
\hline & & & & $(3-4)$ & & $(4-6)$ & & $(6-8)$ & & $(8-10)$ \\
\hline 1 & Western Maharashtra & 2.32 & 3.42 & 57.27 & 4.42 & 36.74 & 5.97 & 53.01 & 7.64 & 30.15 \\
\hline 2 & Vidarbha & 0.05 & 0.058 & 59.96 & 0.08 & 36.66 & 0.3 & 422.21 & 0.48 & 53.4 \\
\hline 3 & Marathwada & 0.456 & 0.456 & -1.86 & 0.97 & 127.12 & 2.282 & 144.86 & 2.56 & 22.42 \\
\hline 4 & Konkan & 0.01 & 0.03 & 8.33 & 0.03 & -11.1 & 0.01 & -38.9 & 0 & -33.33 \\
\hline 5 & North Maharashtra & 0.34 & 0.29 & -16.9 & 1.02 & 290.25 & 1.76 & 71.2 & 1.4 & -10.65 \\
\hline 6 & Maharashtra & 0.83 & 1.09 & 31.3 & 1.62 & 48.6 & 2.45 & 51.2 & 3.2 & 29.2 \\
\hline
\end{tabular}

Table 10. Area under Fruits and Vegetables as Proportion of total cropped area in Maharashtra (\%)

\begin{tabular}{|c|c|c|c|c|c|c|c|c|c|c|}
\hline 1 & 2 & 3 & 4 & 5 & 6 & 7 & 8 & 9 & 10 & 11 \\
\hline \multirow{2}{*}{ Sr. No. } & \multirow{2}{*}{ Region } & \multirow{2}{*}{$1960-61$} & \multirow{2}{*}{$1970-71$} & Change & \multirow{2}{*}{$1980-81$} & Change & \multirow{2}{*}{$1990-91$} & Change & \multirow{2}{*}{ 2001-02 } & Change \\
\hline & & & & $(3-4)$ & & $(4-6)$ & & $(6-8)$ & & $(8-10)$ \\
\hline 1 & Western Maharashtra & 0.97 & 1.36 & 40.47 & 1.49 & 7.04 & 2.68 & 104.62 & 0.44 & -77.07 \\
\hline 2 & Vidarbha & 0.65 & 0.88 & 23.17 & 1.3 & 60.6 & 1.9 & 66.97 & 26.71 & 2528.82 \\
\hline 3 & Marathwada & 0.42 & 0.42 & 0.42 & 0.47 & 22.78 & 1.54 & 332.62 & 16.88 & 1410.62 \\
\hline 4 & Konkan & 1.44 & 2.89 & 90.9 & 3.36 & 11.23 & 5.69 & 53.63 & 0 & -100 \\
\hline 5 & North Maharashtra & 1.1 & 2.27 & 112.9 & 3.02 & 37.3 & 3.23 & 17.45 & 28.95 & 906.6 \\
\hline 6 & Maharashtra & 0.78 & 1.13 & 44.9 & 1.41 & 24.8 & 2.8 & 98.58 & 14.8 & -93.6 \\
\hline
\end{tabular}




\section{REFERENCES}

[1] AFDB (2011), Infrastructure and Agriculture Productivity in Africa, Market Brief, African Development Bank, November.

[2] Aggrawal, B. (1983), Machanization in Indian Agriculture-An Analytical Study based on Punjab. Monograph, Delhi School of Economics

[3] Binswanger, H.P., Khandker, S.R. and Rosenzweig, M.R. (1993) How Infrastructure and Financial Institutions Affect Agricultural Output and Investment in India, Journal of Development Economics, Vol. 41, pp. 337-366.

[4] Binswanger. H.P. (1978), The Economics of Tractors in South Asia, Agricultural Development Council, New York and ICRISAT, Hyderabad.

[5] Dhawab B.D. (1988), Irrigation in India's Agricultural Development: Productivity, Stability, Equity, Sage Publications India, New Delhi, India.

[6] Fan, S., P. Hazell (1999), Are Returns to Public Investment Lower In Less Favored Rural Areas? An Empirical Analysis of India, Discussion Paper 43, Environment and Production Technology Division, International Food Policy Research Institute, Washington D.C.

[7] Gollin, D. and Rogerson, R. (2010), Agriculture, Roads and Economic Development in Uganda, National Bureau of Economic Research WP 15863, Cambridge.

[8] Khachatryan, A., M.V. Oppen, R. Doluschiz, and N. Khachatryan (2005), Response of Plant Productivity to Improved Agricultural Markets in India: Application of an Advanced Econometric Cross-Section Times Series Analysis' Paper Presented at the International Agricultural Research for Development, Oct. 11-13, Stuttgart-Hohenheim, Germany.

[9] Khandekar, S. (1998), Improving Rural Wages in India, WP 276, World Bank, Washington, D.C.

[10] Majumdar, R. (2002), Infrastructure and Economic Development: A Regional Analysis, Centre for the Study of the Regional Development, JNU, New Delhi.

[11] Manalili, R. and L. Gonzales (2009), Impact of Infrastructure on Profitability and Global Competitiveness of Rice Production in the Philippines, hppt://www.irri.org

[12] N.S. Thakur (2003) Research on Crops, Gaurav Society of Agricultural Research Information Center, Hissar, Vol. 4 (3), 2003, pp-305-309.

[13] N.S. Thakur (2003) Research on Crops, Gaurav Society of Agricultural Research Information Center, Hissar,Vol. 4 (3), 2003, pp-305-309.

[14] Narayanamoorthy, A. (2013), Profitability in Crops Cultivation in India: Some Evidence from Cost of Cultivation Survey Data, IJAE, Vol. 68, No. 1, pp-104-121.

[15] Narayanamoorthy, A. and Alli P (2012), India's New Food Security Worries - From Crop Holiday to Declining Foodgrains Area, IJAE, Vol. 67. No. 3, July-Sep.

[16] Padmavati, (2005) J. Oilseeds Research , Science \& Technology- J, Division of Agronomy, Kashmir University of April, R.S. Pura, Jammu, Vol.- 22 (2), Dec. 2005, pp-
435-437.

[17] Rao, T.R. (1978), Agricultural Mechanization in Retrospect, Proceedings of Symposium on Farm Mechanization-Problems and Prospects, ISAE and Punjab Agricultural University, Ludhiana, pp-45-56.

[18] Raskar, B.S. Bhoi. P.G. and Shinde. S.H. (2000), Yield and Economics of Soya beans (Glycine max) Based Cropping Sequences under Irrigated Conditions, Indian Journal of Agronomy, 45: pp-477-482.

[19] Raskar, B.S. Bhoi. P.G. and Shinde. S.H. (2000), Yield and Economics of Soya beans (Glycine max) Based Cropping Sequences under Irrigated Conditions, Indian Journal of Agronomy, 45: pp-477-482.

[20] Reddy and Reddy (2005) Indian Journal of Agricultural Marketing, Indian Society of Agricultural Marketing, Seminar Hill Nagpur. Vol- 19(3), Sept to Dec. 2005. pp21-29.

[21] Shrikant S. Kalamkar (2003), Artha Vijnana, Vol-XL-V, No. 3-4, September-December, 2003, pp-297-324.

[22] Singh, Lohan, Jat and Rani (2006), Research on Crops, Gaurav Society of Agricultural Research Information Center, Hissar, Vol. (2), Aug. 2006, pp-369-371.

[23] Sngh and Rathore, (2003), Research on crops. Gaurav Socity of Agri Research Information Center, Hissar, Vol, 4(2), Aug. 2003, pp. 210-112.

[24] Sngh and Rathore, (2003), Research on crops. Gaurav Socity of Agri Research Information Center, Hissar, Vol, 4(2), Aug. 2003, pp-210-112.

[25] Spencer, D.S.C. (1994), Infrastructure and Technology Constraints to Agricultural Development in the Humid and Sub-Humid Tropics of Africa, Environment and Production Technology Division, International Food Policy Research Institute, Washington D.C.

[26] Thakur, Pannase and Sawarkar (200O), Research on Crops. An Gaurav Society of Agri Research Information Center, Hissar. Vol.1(2), Jan 2000, pp- 171-175.

[27] Thakur, Pannase and Sawarkar (200O), Research on Crops. An Gaurav Society of Agri Research Information Center, Hissar. Vol.1(2), Jan 2000, pp- 171-175.

[28] Thorat, S. and Sirohi, S (2002), Rural Infrastructure State of Indian Farmer: A Millennium Study, Ministry of Agriculture, GoI. New Delhi.

[29] Tomar R.K.S., Namdeo, K.N. and Raghu, J.S. (1996), Yield and Economics of Double Cropping with Pulses and Oilseed Against the Base Crop wheat. Indian Journal of Agronomy, 41: pp-205-208.

[30] Vaidyanathan (2006), EPW, Samiksha Trust Publication, Vol. XL, No. 27 \& 28, July, 8-14, 15-20, 2006. pp- 2984 - 2987.

[31] Vaidyanathan, A. (1999), Water Resources Managemennt: Institutions and Irrigation Development in India, Oxford University Press, New Delhi.

[32] Venkatachalam, L. (2003), Infrastructure and Agriculture Development in Karnataka State, Institute for Social and Economic Change, Bangalore.

[33] Yan de Walle, D. (2002), Choosing Rural Roads Investments to Help Reduce Poverty, World Devel;opment, Vol. 30, No. 4, 
pp-575-589.

[34] Zhang, X. and S. Fan (2000), Public Investment and Regional
Inequality in Rural China, Discussion Paper No. 71, Environment and Technology Division, International Food Policy Research Institutte, Washington D.C. 